\title{
Staff training and development programmes in academic libraries in Imo State, Nigeria
}

\author{
Charity O. Iwuchukwu \\ Assistant Librarian, \\ Federal University of Technology, Owerri \\ Imo State, Nigeria \\ E-mail: ciwuchukwu9@gmail.com \\ Cell: +2348064237062 \\ Anthonia U. Echedom, Prof \\ Department of Library and Information Science, \\ Nnamdi Azikiwe University, Awka, \\ Anambra State, Nigeria \\ E-mail: tonianwabueze@yahoo.com \\ Cell: +2348034908733
}

\begin{abstract}
This study examined the staff training and development programmes in academic libraries in Imo State, Nigeria. Five research questions guided the study. Descriptive Survey research design was adopted for the study. All academic librarians in five institutions of higher learning in the state, comprising 81 academic librarians were investigated. Structured Questionnaire was used to collect data for the study. Data generated were analyzed using percentage, frequency and arithmetic mean rating. Findings of this study showed that there are available training and development programmes in academic libraries in Imo state to a high extent; library needs, institutions objectives, librarians request/staff need are the criteria used to select librarians to attend staff training and development programmes. Challenges of staff training and development programmes in the academic libraries according to the study include: poor funding, and lack of management policy on training and development programmes. The study concluded that there should be continuous educational and professional programmes for librarians to update their knowledge on new technology, and adequate infrastructural facilities should be provided in academic libraries to enable librarians practice what they learnt.
\end{abstract}

Keywords:, Staff training and development programmes, Academic libraries, Imo State, Nigeria

\section{Introduction}

The hallmark of every organization is its human resources. Institutions of higher learning like universities and colleges are labour intensive organizations and depend on people for the delivery of services. Thus, effectiveness of academic libraries depends on the efficiency of their staff training and development programmes. Staff training and development programmes cover a broad range of activities designed to provide staff with the knowledge and skills that are related to their roles and responsibilities in the library (Osigbemhe, 2007).
Academic libraries are set up in higher institutions solely to support teaching, learning and research. Osigbemhe (2007) stated that academic libraries are the core of the academic set up as a result of the information resources relevant to the various disciplines being pursued in the institutions held in the library. Castelyn (2007) noted that the goal of every library is to have efficient staff in order to provide good library services to the society they serve. The most crucial element in effective information service delivery in this 
Iwuchukwu, Charity O. and Echedom, Anthonia U.: Staff training and development programmes in academic libraries in Imo State, Nigeria

information age is having the right staff with the appropriate information technology skills in place. Staff training and developmenttherefore, is of utmost importan ce in the library especially in this present knowledge age, where information technologies are infused in almost all human endeavoure. In the library, this infusion has significantly created the need for changes in the tools and roles of libraries requiring new information technological skills in addition to traditional library skills (Gbaje\&Ukachi, 2011). Hence, staff training and development programmes should be designed to ensure efficient performance to the dual goal of the library system and the user (Asante \&Alemna, 2013).

Fadehan and Ali (2006) stated that the competencies or skills available to academic librarians in their current and future job remain a problem to be solved and that the $21^{\text {st }}$ century has witnessed an unprecedented paradigm shift in the rendering of library and information services world-wide. For libraries to remain relevant in the current trend there is need for staff training and development programmes in the line of informing the library staff on the latest trends in making the library functionally effective to the users. Olaniyan and Ojo (2008) asserted that training is a systematic development of knowledge, skills, and attitudes required by academic librarians to perform effectively in service delivery. Staff training and development according to Oduagwu (2006) is the aspect of capacity building aimed at having skilled, knowledgeable and competent staff for enhancement of user satisfaction and the achievement of libraries objectives through effective service delivery. Oduagwu further stated that it encompasses those activities which strengthen the knowledge, ability and behavior of the librarian and improve institutional structures and processes such that the library requires the intellectual and professional services of men and women who have been trained for such purpose. Training, both physically, socially and intellectually are very essential in facilitating not only the level of effective and efficient service but also the development of librarians in any academic library (Olaniyan \& Ojo, 2008).

Ifidon (2004) enumerated the aims of staff training and development in the library as follows: to enable the librarian make more effective contributions to the library's total effort in its service mission; to make the individual look for satisfaction which go beyond self-pride, self-respect and economic achievement; to prepare the staff for the challenges of complex modern technology which requires integration of activities and persons of diverse and specialized competence; to enable the professional library staff develop life of their own outside the academic library; to make the staff receptive to change and innovative rather than resistant to them.

Audibia (2002) stated that today's fast changing world, with its rapidly transforming social, economic, political and technological factors brings constant modification in the internal and external business environment. Audibia further stated that training and development of library personnel through its effectiveness and influence over the behavior, skill, potential and capabilities of the employees, acts as a formidable tool for dealing successfully with the complex nature of challenges that confront the academic library. Yan, (2004) emphasized that in the past, the more printed materials an academic library could collect, and organize, the easier it would be for the academic library to meet their user's need. According to Yan, the quality of an academic library was therefore measured mainly by its holdings.

But today in the $21^{\text {st }}$ century, the development in computing and telecommunication has made it possible for academic libraries to provide their users 
Iwuchukwu, Charity O. and Echedom, Anthonia U.: Staff training and development programmes in academic libraries in Imo State, Nigeria

with a wide range of text, image and sound resources from around the world. The academic libraries setting are changing from offering users limited warehouse of information to global gateway, leading to infinite net-distributed information resources. The academic libraries should be evaluated by their ability to provide information on demand, regardless of the source, and the effectiveness of the technical system employed to locate and retrieve from world-wide information resources. Library is not a static venture as it is dynamic (Abudlahi, 2001). Therefore, the way library acquires, processes, stores and disseminates information has been changing over time, and if the academic library staff is not capable or trained properly to handle such technical and professional works, the whole process of satisfying the library user goes in vain.

There are activities designed to provide librarians with the knowledge and skills needed for effective and efficient service delivery and, the achievement of libraries' objectives. These include conferences, seminars, workshops, further studies, orientation, and on the job training. This study therefore, aims at determining the extent of training and development programmes in academic libraries and how these programmes affect the performance of librarians in academic libraries in Imo state.

\section{Statement of the problem}

Academic libraries have usually been seen as custodians of books and journals for the academia and taking statistics of users visiting the libraries. In the past, the more printed materials an academic library could collect and organize, the easier it would be for the library to meet its user's information need. The quality of an academic library was therefore measured mainly by its holdings. But the challenge that is arising out of globalization of information technology is that the new era academic libraries have to provide the desired services to their clients beating space and time. Academic libraries now have innovative library services and data bases for effective service delivery.

Due to the proliferation of digital information over the internet, library services are losing their former unique place in the society they serve, they are no longer indispensable to their end users since the users can easily consult many of their information systems available on the internet. Due to the new technologies and information systems, librarians are expected to master and acquire navigational skills on these technologies and information systems for effective service delivery to library users. This will help them become relevant in the knowledge drive society. Hence, librarians need to learn and participate actively in the collaborative information environment in its current form in order to be relevant in the scheme of things. However librarians need to be relevant of advanced technology and should keep up with new information format. Several empirical studies (Okafor, 2007, Ajidahun 2007,Adeniji,Babalola and Adeniji 2012, Eze and Uzoigwe 2013, Anunobi 2013) have been carried on benefits and challenges of staff training and development programs in academic libraries. This means that adequate training and development programmes should be in all academic libraries through thoughtful and well defined need analysis to accommodate modern and latest developments in librarianship. It is against this situation that this study on Prospects and Challenges of staff training and development programmes in academic libraries in Imo State is embarked upon.

\section{Objectives of the study}

The objective of this study was to explore staff training and development programmes in academic libraries in Imo State, Nigeria. Specifically, the study set out to: 
Iwuchukwu, Charity O. and Echedom, Anthonia U.: Staff training and development programmes in academic libraries in Imo State, Nigeria

1. identify the types of staff training and development programmes in academic libraries in Imo State;

2. ascertain the criteria used by academic libraries to select librarians for staff training and development programmes;

3. find out the extent to which academic libraries benefit from staff training and development of their professional staff in Imo State;

4. identify the challenges of staff training and development programmes in academic libraries in Imo State; and

5. find out ways to improve professional staff training and development programmes in academic libraries.

\section{Research questions}

The following research questions are answered in this study:

1. What type of staff training and development programmes are available to librarians in academic libraries in Imo State?

2. What criteria do academic libraries in Imo State use to select librarians to attend staff training and development programmes?

3. To what extent do academic libraries in Imo State benefit from staff training and development of their professional staff?

4. What are the challenges to staff training and development programmes in academic libraries in Imo State?

5. What are the ways to improve staff training and development programmes in academic Libraries in Imo State?

\section{Literature review}

Staff training is a process by which workers continuously update their knowledge and renew the work skill in order to be able to compete effectively in our changing society (Eyo, Nkanu \& Ogar, 2013). Aina (2004) asserted that staff training is various ways librarians working in the libraries acquire core competencies and new skills so that they never become obsolete anytime in this fast changing environment. Oduagwu (2006) asserted that staff training and development is the aspect of capacity building aimed at having skilled, knowledgeable and competent staff for enhancement of user satisfaction; achievement of libraries objectives through effective service delivery. Chandan (2000) described staff training as a short term process which uses systematic and organized procedure to enhance the knowledge and skills of personnel. According to Chandan, it is seen as part of vocational or career development which helps to overcome the problem of obsolensce. Staff training refers to a planned effort by an organization to facilitate employees' learning of job related competencies (Noe, 2010). These competencies according to Noe include knowledge, skills or behaviours that are critical for successful job performance. Audibia (2002) stated that staff training is an educational process which enable people learn new information, re-learn and reenforce existing knowledge and skills and most importantly have time to think and consider what new options that can help them improve their effectiveness at work. According to Armstrong (2009), training is the means by which a person can acquire and develop new knowledge, skills, capabilities, behaviours and attitudes. Armstrong further stated that it involves the application of formal processes to acquire the skills necessary for them to perform their jobs satisfactorily. 
Iwuchukwu, Charity O. and Echedom, Anthonia U.: Staff training and development programmes in academic libraries in Imo State, Nigeria

Staff training according to Eze and Uzoigwe (2013) is a systematic approach to staff development and continuing education that is usually in form of a programme of learning opportunities aimed at ensuring that workers continue to acquire and adapt their skills and knowledge to a changing environment. Obi and Zakari, (2007) posited that staff training is an attempt to improve current or future employee performance through learning, an employee's ability to perform, usually by increasing the employee's skills and knowledge. Reynolds (2002) emphasized that staff training is one of the several responses an organization can take to promote learning. Onwubiko (2004), is of the view that staff training and development is an integrated management function designed to move personnel into, through and eventually out of an organizational marching skills available and training them on the task to be performed now and in future. Conroy (2003), stated that the purpose of staff development is to prepare the personnel and the library for the future, enabling each to contribute to the growth of others. According to Danladi (2013), staff training is the necessary tonic that enables the personnel in the library to acquire and posses the necessary skills, capabilities and attitudes needed for efficient performance of their duties. Danladi is also of the view that staff training is seen as the activities that academic librarians use to upgrade their knowledge, abilities, competencies and understanding in their field of work or specialization so that they can become more effective professionals and to be able to handle responsibilities of greater scope and accountability.

In fact; adequate staff training and development programmes will enable academic libraries to access, organize, evaluate and communicate information resources to the satisfaction of library users. Thus, it is essential that academic libraries should develop the skills of librarians through staff training and development programmes to enable them function effectively and efficiently in the $21^{\text {st }}$ century.

Okafor (2007) described training and development programmes as the teaching of technical skills to the employees of an organization. According to Okafor, they are the programmes that are put together to improve the technical human relations and skills of employees in an organization. Training and development programmes according to Gbaje and Ukachi (2011), are the cornerstone of any effort to retool library staff to meet the challenges and opportunities of a digital work environment. Audibia (2002) emphasized that training and development constitute a systematic process of altering the behaviour of employees in a direction to increase organizational effectiveness and efficiency. Armstrong (2009) stated that training and development programmes are concerned with ensuring that person's ability and potentials are grown and realised through the provision of training or through self -directed learning. Armstrong further stressed that, it is a process that enable people to progress from a present state of understanding and capability to a future state in which high level skills, knowledge and competencies are required, and that, it takes the form of training activities that prepare people to exercise wider or increased responsibilities. Cordis (2000) posited that training and development are two interactive concepts to equip one for skills required on the job for personal and organizational development.

Every academic library should have a critical insight and clear view of what success looks like (Daniel, 2012). Academic libraries and information professionals must of necessity develop expert technological competencies required to make the best use of opportunities the ICT offers in order to meet the services of the changing complex 
Iwuchukwu, Charity O. and Echedom, Anthonia U.: Staff training and development programmes in academic libraries in Imo State, Nigeria

information needs of the user community (Ramana in Ochai, 2012).

Anasi and Ali, (2013) stated that, academic libraries need to be as savvy as the clients they serve, and the most productive and effective way for libraries to keep up with changes of information landscape is to seek out professional development opportunities. Yosuf (2000) agrees that training of personnel enhance productivity. According to Yusuf, training and development are generally indicated as the most important direct means of upgrading the human intellect and skills for productive employment. Stoner, (2002) emphasized, that training programmes should be directed towards improving efficiency and job performance. Stoner further stated that, there is no doubt that staff trained in information technologies will be more efficient in the use of information and computer facilities than those who never had such training experience. Therefore, staff training and development improves job performance and promotes management efficiency. According to Danladi (2013), no library professional would be able to meet his/her responsibilities without taking the trouble to keep pace with trends in the field of librarianship through exchange of ideas at seminars conferences, workshops, formal study.

Library profession is very dynamic and with all the challenges taking place, they need to keep with the developmental and current trends facing the profession. Ajidahun, (2007) stated that training is an integral part of vocational or career development and it is fast becoming a global and pervasive phenomena in any establishment, the absence of which spells doom for such an institution, and the presence of which determines the success of any enterprise. The academic libraries no doubt cannot do without adequate training of their professional staff to be dynamic enough to cope with the changing needs of the patrons. Danladi (2013) is of the view that academic librarians need to upgrade their knowledge, abilities, competencies and understanding in their field of work or specializations so that they can become more effective professionals and to be able to handle responsibilities of greater scope and accountability. He further stated that librarians need to embark on training and development as not all academic librarians are computer highway, the computer and other telecommunication technologies are gradually taking over the manual process, hence the need for academic libraries to educate their librarians for them to keep pace with current trends.

Academic libraries need to reshape the vision of academic librarianship and adopt some concepts and principles to guide library management for better services. Abba (2009) asserted that lack of staff training results in lack of ability to use existing knowledge which causes ineffective services, lack of customer satisfaction and lower productivity. Abba further stated that, staff training will foster an increase professionalism and better management method, whereas lack of staff training can cause frustration and lack of job satisfaction. Well trained individuals know the scope and expectations of their jobs and will be able to add building- blocks to their expertise as they progress through their careers. The changing nature of library users and the demand for managers with appropriate skills have added to the need for training (Abba, 2009). These developments and pressures have had a profound impact on academic librarianship. To engage librarians in staff training will have an immeasurable impact on them and the library.

According to Obi (2013), the general benefits derived from personnel training in academic libraries is that the librarians are motivated, productive and skilled in their jobs and they are able to understand and implement library policies to its parent 
Iwuchukwu, Charity O. and Echedom, Anthonia U.: Staff training and development programmes in academic libraries in Imo State, Nigeria

organization. Obi indicated that training of librarians will help: prepare the librarian both new and old to meet the present, as well as the changing requirements of the job and the library; prevent obsolescence in libraries; build up competent librarians and prepare them to occupy more responsible positions; helps to develop the potentials of people for the next level job; assist the librarian to function more effectively in their present positions exposing them to the latest concepts, information and technique and developing the skill they will need in their particular fields; ensure smooth and efficient working of a department. Training of librarians will earn them good salary increment, easy conversion, promotion, more efficiency in their work areas, better exposure and capability of interaction with fellow workers and users, and selfdevelopment (Onyia \& Aniogbolu, 2011).

In Adeniji and Babalola (2012), staff

training has promoted effective communication among the management team of the library thereby leading to the achievement of the organizational goal, It has helped the librarian to translate theoretical concepts to meeting users information needs, Training has equipped staff to understand and appreciate library management and administrative practices. Training offers the library effective leadership with vision commitment and good negotiation skills, tested market strategies and adventurous public relations work. Obichere (2013) outlined the benefits of staff training and development as adequately trained and developed staff improve library services, improve library management and good staff relationship, adequate control and discipline of staff.

Training in academic libraries usually meets stumbling block which include: financial constraint: this is seen as a major factor militating against personnel training programmes in academic libraries in Nigeria. Okafor, (2007) asserted that finance is the fundamental molding factor in the planning and execution of library programmes. The successful implementation of any library programmes tremendously dependent on the availability of funds to the library, but in a situation where the libraries are constantly under-funded leaves much to be desired in the area of realizing the goals of library staff training. Eze and Uzoigwe (2013) indicated that inadequate funding militates against training of librarians. They emphasized that without adequate funding, acquisition of infrastructure and facilitation of other related logistics required to organize such special training will be hindered and without government commitment to the issue of advancing the library system, funding of libraries may never be adequate. Anunobi (2013) observed that staff capacity development in Nigerian university libraries was challenged by inadequate finance to send staff on training, and where training had been provided; there are no facilities to implement the acquired skills. Other challenges according to Anunobi include: trained librarians migrate to other institutions on completion of training. There is also limited opportunities because training outside the country is very expensive than training within the country. This is why there are limited numbers of people who are sent for training at the same time which may pose a problem in skills development (Obi, 2013). Senyah ( 2002), stated that the cost of training staff is very high and budgetary allocations of libraries suffer drastically in training staff. Senyah opined that, there may be lack of awareness of the importance of the training and, difficulties choosing the beneficial training from the commercial motivated training outfit.

Ugwuanyi and Ejikeme (2011) stated various challenges of staff training and development one of which is staff resistance to change. According to them, many members of staff in academic and research libraries tend to resist the introduction and 
Iwuchukwu, Charity O. and Echedom, Anthonia U.: Staff training and development programmes in academic libraries in Imo State, Nigeria

use of ICT's because they have not been adequately trained to appreciate their usefulness in this technological age. This may be as a result of lack of interest, lack of knowledge of what to teach, limited opportunities on skill acquisition, and, selection of right ICT technology. Unreliable power supply is also an impediment in achieving the manpower goals of the new era, together with constant change of software and hardware. Others include poor responsive attitude on the part of management; neglect from authority and non-availability of budget allocation for training programmes for library personnel as factors blocking the full realization of personnel training programmes in academic libraries. Obichere (2013) outlined the challenges of staff training and development as favouritism, budgetary insufficiency, and bureaucratic bottlenecks from the management. According to Obichere, lack of interest on the part of the librarians may also be a factor as many librarians are not interested to develop themselves. Many wait until they are sponsored.

\section{Methods}

Descriptive Survey Research design was used for this study. The study was conducted in five institutions of higher learning in Imo State.

Population of the study consisted of eighty one (81) librarians in five institutions of higher learning in Imo State (See Table $1)$.

Table 1: Population and sample of the study

\begin{tabular}{lc}
\hline Name of Institutions & Number of librarians \\
\hline Federal University of Technology & 36 \\
Owerri & 23 \\
Imo State University, Owerri & 9 \\
Federal Polytechnic, Nekede & 4 \\
Imo State Polytechnic, Umuagwo & 9 \\
Alvan Ikoku Federal College of & \\
Education & $\mathbf{8 1}$ \\
Total
\end{tabular}

A questionnaire was used as instrument of data collection in this study. The instrument was face validated by two lecturers from the Department of Library and Information Science and one lecturer from the Department of Educational Foundations (Measurement and Evaluation option), Faculty of Education, Nnamdi Azikiwe University, Awka. Reliability of the instrument was established using Kuder Richdson 20 (KR-20) and Cronbach's alpha Methods. Both methods involved single administration of instrument. Data generated was analyzed using percentages, frequencies and arithmetic mean. Percentages and
Frequencies were used to analyze research question one. Arithmetic mean was used to analyze research questions two, three, four, and five. The pass mark for the frequency and percentage analysis was 50 percent and above.

Mid-point for responses in four (4) points scale was used for questions $2-5$. The four (4) points scale was 2.50. Therefore, the criteria or basis for decision was such that items to the values of 2.50 and above were interpreted as "agree " while items with the value below 2.50 were interpreted as "disagree" . 
Iwuchukwu, Charity O. and Echedom, Anthonia U.: Staff training and development programmes in academic libraries in Imo State, Nigeria

Decision rule for research question one(1) include:

50-100\% - available

$0-49 \%$ - not available

Research question two(2) to five (5) includes Very high extent/strongly agree is 3.50-4.00

High extent/ agree is $2.50-3.49$

Low extent/disagree is 2.00-2.49

Very low extent/strongly disagree is 1.00-1.99.

Items to the values of $50 \%$ and above were given positive interpretation (available). Items to the values of 2.50 and above were given positive interpretation (High extent) while items to the values below 50\% and 2.50 and below were interpreted negatively (Low extent).

\section{Results}

Research question one: What are the types of staff training and development programmes available to librarians in academic libraries in Imo State?

The data in Table 2 are used to answer this question.

Table 2: Staff training and development programmes available in academic libraries

\begin{tabular}{clccccc}
\hline $\begin{array}{l}\text { Types of staff training } \\
\text { development programmes }\end{array}$ & and Available & \multicolumn{3}{c}{ Not Available } & \\
& & Freq. & \% & Freq. & & Decision \\
\hline 1. Orientation & 76 & 93.8 & 5 & 6.2 & Available \\
2. Job rotation & 79 & 97.5 & 2 & 2.5 & Available \\
3. On-the-job training & 75 & 92.6 & 6 & 7.4 & Available \\
4. In-house Training & 60 & 74.1 & 21 & 25.9 & Available \\
5. Study visit & 25 & 30.9 & 56 & 69.1 & Not-Available \\
6. Conferences & 81 & 100 & - & - & Available \\
7. Seminars & 78 & 96.3 & 3 & 3.7 & Available \\
8. Workshops & 77 & 95.1 & 4 & 4.9 & Available \\
9. Formal professional & 75 & 92.6 & 6 & 7.4 & Available \\
& library education & & & & & \\
\hline
\end{tabular}

Table 2 shows the frequency and percentages of the staff training and development programmes available in academic libraries in Imo state. The analysis shows that out of the nine staff training and development programmes listed, eight were available in academic libraries in Imo state. They include: Orientation (93.8\%), Job rotation $\quad(97.5 \%)$, On-the-job-training (92.6\%), in-house visit $(74.1 \%)$, Conferences (100\%), seminars $(96.3 \%)$, workshops (95.1\%) and formal professional library education (92.6\%). All had over 50\% available study visit was not available $(30.9 \%)$

Research question two: What criteria do academic libraries in Imo State use to select librarians to attend staff training and development programmes?

The data in Table 3 are used to answer this question. 
Iwuchukwu, Charity O. and Echedom, Anthonia U.: Staff training and development programmes in academic libraries in Imo State, Nigeria

Table 3: Criteria used by academic libraries in Imo State to select librarians to attend staff training and development programmes.

Criteria used to select librarians to attend staff training and development programmes

N Mean Decision

1. When the library needs skilled staff in a $81 \quad 3.07 \quad$ Agree particular area

2. Institutions objectives on the policies of training $\quad 81 \quad 2.94 \quad$ Agree and re-training of librarians

3. On the requested of the librarian to attend $81 \quad 2.98 \quad$ Agree training and when the librarian need the training because of the specified job being handled

The analysis in Table 3 show that the respondents agreed that the three listed criteria are being used by academic libraries

in selecting librarians to attend staff training and development programmes. The mean for the three items ranges from 2.94 to 3.07.
Research question three: To what extent do academic libraries in Imo State benefit from staff training and development programmes of their professional staff? This research question is answered with the data in Table 4.

Table 4: Extent to which academic libraries benefited from staff training and development of their professional staff

Benefit of staff training and development programmes to academic libraries

\section{$\mathbf{N}$}

81

81

81

3. The librarian is able to take greater responsibility

4. The librarian will work with competency/efficiency 81

Grand Mean
$81 \quad 3.26 \quad$ High Extent

$3.56 \quad$ High Extent

3.44

High Extent

3.57 High Extent

$3.46 \quad$ High Extent
Table 4 shows the grand mean of 3.46 which is an indication that the extent to which libraries in Imo State benefited from staff training and development programmes of their professional staff is high. The analysis of the individual items shows that libraries benefited from the four listed staff training programs of their professional staff to a high extent. The mean for the four items ranges from 3.26 to 3.57 .
Research question four: What are the challenges that impede staff training and development programmes in academic libraries in Imo State?

This research question is answered with the data in Table 5. 
Iwuchukwu, Charity O. and Echedom, Anthonia U.: Staff training and development programmes in academic libraries in Imo State, Nigeria

Table 5: Challenges that impede staff training and development programmes in academic libraries.

\begin{tabular}{lllll}
\hline $\begin{array}{l}\text { Challenges that impede staff training and } \\
\text { development programmes }\end{array}$ & $\mathbf{N}$ & Mean & Decision \\
\hline $\begin{array}{l}\text { 1. Poor funding } \\
\text { 2. Lack of management policy to guide training and }\end{array}$ & 81 & 3.31 & Agree \\
$\quad$ development programmes librarians & & & Agree \\
3. Inadequate training facilities & 81 & 2.96 & Agree \\
4. Poor staff relationship with management & 81 & 2.70 & Agree \\
5. Poor management attitude and less dedication to staff & 81 & 2.86 & Agree \\
training and development & & & \\
\hline
\end{tabular}

Table 5 shows that the respondents agree that the five listed items are the challenges that impede staff training and development programmes in academic libraries. The mean of the five items ranges from 2.70 to 3.31 .

Research question five: What are the ways to improve staff training and development programmes in academic libraries in Imo State?

This research question is answered with the data in Table 6.

The analysis in Table 6 shows that the respondents agree that the 6 listed items are ways of improving staff training and development programmes in academic libraries. The mean of the six items ranges from 3.56 to 3.73 . 
Iwuchukwu, Charity O. and Echedom, Anthonia U.: Staff training and development programmes in academic libraries in Imo State, Nigeria

Table 6: Ways to improve staff training and development programmes in academic libraries.

Ways to improve staff training and development $N$ Mean Decision
programmes

1. Academic libraries should organize continuous $81 \quad 3.73$ Agree educational and professional programmes for professional librarians to update their knowledge on new technology

2. Job rotation / lateral transfer should be done within the $81 \quad 3.64$ Agree academic library to enhance training and development of librarians

3. Library management should from time to time 813.72 Agree organize in-house training for librarians

4. Librarians should participate in conferences, seminars and workshops to enhance their development to enable them improve on their services.

5. Sufficient fund should be granted to academic libraries by the parents' institutions to enhance the training and development of librarians

6. Adequate infrastructural facilities should be provided in academic libraries to enable librarians practice what they learnt

7. Cordial relationship should be maintained between librarians and the library management to promote sustainable training and development programmes in academic libraries.

8. Government agencies should give enough sponsorship $81 \quad 3.64$ Agree grants to academic libraries through their parent institutions to enhance training and development of librarians.

\section{Discussion}

This study revealed that different types of training and development programmes are available to librarians in academic libraries in Imo state. The finding is in line with the findings of Ogbonna (2000); Okafor (2007) and Anunobi (2013), whose studies revealed that there are available training and development programmes in academic libraries. These findings are relevant as they have provided further evidence that staff training and development programmes are available in academic libraries.

This study discovered that libraries needs, institutions objectives and on the request of the librarian/staff need are the criteria used by academic libraries in selecting librarians to attend staff training and development programmes. This result is in line with the work of Ajidahun (2007), who reported that before selecting librarians for training, identification of the worker's need and library's benefits for training should be considered.

This study with a grand mean of 3.46 that academic libraries in Imo State benefited from staff training and development programmes of their librarians to a high extent.The finding is in line with the study of Danladi (2013) who opined that no library professional would be able to meet his/her responsibilities without taking 
Iwuchukwu, Charity O. and Echedom, Anthonia U.: Staff training and development programmes in academic libraries in Imo State, Nigeria

the trouble to keep pace with the trends in the field of librarianship through exchange of ideas at seminars, conferences, workshops, and formal study. Obi (2013) also revealed that the general benefit derived from personnel training in academic libraries are motivation, productive, and skilled librarians, and that librarians are able to understand and implement library policies to its parent organization. Obi revealed that training and development in academic libraries help to prepare the librarian both new and old to meet the present as well as the changing requirements of the job and the library; prevent obsolescence in libraries; build up competent librarians and prepare them to occupy more responsible positions.

The study also revealed that various factors hinder staff training and development programmes in academic libraries in Imo state. These factors include; financial constraint; Lack of management policy to guide training and development of librarians, Inadequate training facilities, Poor staff relationship with management, poor management attitude and less dedication to staff training and development. The finding is in line with Eze and Uzoigwe (2013) who indicated that inadequate funding militates against training of librarians. Eze and Uzoigwe emphasized that without adequate funding, acquisition of infrastructure and facilitation of other related logistics required to organize such special training will be hindered. Okafor (2007) also revealed that a situation where the libraries are constantly underfunded leaves much to be desired in the area of realizing the goals of the library staff training and development. Ugwuanyi and Ejikeme (2011) opined that staff resistance to change, poor responsive attitude on the part of management are factors blocking the full realization of personnel training programmes in academic libraries. The study revealed various methods of improving staff training and development programmes in academic libraries to include: continuous educational and professional programmes for librarians to update their knowledge on new technology, job rotation and/or lateral transfer, in house training/service training, librarians participation in seminar/workshop and conference, adequate infrastructural facilities, adequate sponsorship from grants by government agencies to academic libraries through their parent institutions to enhance training and development of librarians. This finding is in agreement with Eze (2012) who suggested that the methods for improving staff training and development of librarians include: adequate funding, formulating training policy, clear identification of each workers training need, and the consideration of all workers when planning for training.

\section{Conclusion}

The study has shown that there are different types of Staff training and development programmes in academic libraries in Imo state. This imply that academic libraries have improved in the availability of staff training and development programs to librarians in order to move with current trends and be relevant in the knowledge driven society.

The following recommendations are made based on the findings of this study:

1 Government and/or government agencies should allocate sufficient funds to support staff training and development programmes in academic libraries.

2 Library professional bodies, for instance, National Library Association and Librarians' Registration Council of Nigeria should continuously encourage librarians to attend seminars, workshops, conferences, training 
Iwuchukwu, Charity O. and Echedom, Anthonia U.: Staff training and development programmes in academic libraries in Imo State, Nigeria

programmes on current

developments and

technologies in the field of library.

3 Library management should, from time to time organize in-house training and study visit amongst librarians on the current development and technologies in the field of library. This will help librarians update their knowledge for professional competence.

4 Librarians should endeavor to enroll in continuing professional programmes to improve their knowledge, skills, abilities, and competences in the profession and remain open to new theories, techniques and approaches.

\section{References}

Abba, T. \& Dawha, E.M. (2009). Assessment of personal training needs in the Ibrahim Banbangida library federal university of technology, Yola, Nigeria. Library Philosophy and Practice. unlib.unl.edu/lpp/abba2.htm.

Abdulahi, Y., Kamal, S. \& Anista, Y. (2001). Challenges of information communication technology and the $21^{\text {st }}$ century librarians. Nigerian Journal of Library, Archival and Information Science (NJAIS), vol.1 no $12.35-41$.

Adeniji , M.A , Babalola , G.A \& Adeniji , S.A. (2012). Workers Training Programmes in Two University Libraries in Nigeria. http://www.webpages.uidaho.edu/ mbolin/adeniji-babalola-adeniji.htm

Aina, L. O. (2004). Library and information science text for Africa. Ibadan: Third
World information services Ltd. 1440

Ajidahun, C. O. (2007). The training, development, and education of library manpower in information technology in University libraries in Nigeria. World Libraries 17(1) (http://www.worlib.org/vol17no1prin t/Ajidahunprint.htm.

Anasi, S. N. \& Ali, H. (2013).E-learning and continuing professional development benefit, opportunities and challenges in academic libraries in Lagos state, Nigeria. Compendium of NLA 2013 conference papers at Calabar, Cross River state, $9^{\text {th }}-14^{\text {th }}$ June, 2013. 145165

Anunobi, C. V. (2013). Human capacity building in Nigerian university libraries: an imperative for academic libraries contribution towards national development. Af

Journal of Libraries, Archives uru Information Science, 23(1), 33-44

Armstrong, M. (2001). A Handbook of Human Resource Management Practice. $8^{\text {th }}$ ed. London: Kogan.

Asante and Alanna (2013). Training and development in Polytechnic Libraries in Ghana (Unpublished Mphil Thesis), University of Ghana, Legion. https://digital commons.unl,edu >lib------

Audibia, O. A. (2007). Staff training and development programmes in Abia State civil service. Master dissertation, Abia State University, Okigwe

Castelyn, M. (2007). Training and developing staff: the training function in libraries. UNESCO : New York. Pp1-5.Chandon, J. S. (2000). Management: theory and practice. New Delhi : Vikas publishing house PVT Ltd.

Chandon, J. S. (2000). Management : theory and practise. New Delhi : Vikas 
Iwuchukwu, Charity O. and Echedom, Anthonia U.: Staff training and development programmes in academic libraries in Imo State, Nigeria

publishing house PVT Ltd. https ://books. google. com. ng>books

Conroy, B. (2003). Staff Motivation in Library Administration. London: Bingley. ir.knust.edu.gh $>$ xmlul $>$ pdf

Daniel, J. O. (2012). Building the Requite Capacity for the Library and Information Professionals of the $21^{\text {st }}$ Century. Lagos: Elis Associates, 107-119.

Danladi; M. O. (2013). Training and continuing educational needs in academic libraries; Journal of Education for Library and Information Science. 5(1)

Eyo, E. B. E., Nkanu, W. O. \& Ogar, C. E. (2013). Training and education of innovative and creative librarians in Nigerian university libraries. Being a Paper Presented at NLA 2013 Conference and AGM at Calarbar from $9^{\text {th }}-14^{\text {th }}$ June, 2013. 33-52

Eze, J. U. \& Uzoigwe, C. U. (2013).Training and education of innovative libraries in Nigeria: making librarianship more transparent. Compendium of NLA 2013 Conference Papers at Cross River state, $9^{\text {th }}-14^{\text {th }}$ June, 2013

Fadehan, O. A. \& Ali, H. (2006) Perception of educational needs of librarians in the $21^{\text {st }}$ century digital environment: Case Study of Selected Academic Libraries in Lagos State, Nigeria, Library Philosophy and Practice. www.webpages.uidaho.edu/.../fadeha n-ali.htm.

Gbaje, E. S. \& Ukachi, N. B. (2011).An assessment of technological skills competency of academic LIPS in Nigeria: information for all: Strategies for National Development. NLA $\quad 49^{\text {th }} \quad$ National Conference/AGM, Awka.

Iffidon, S. E. \& Iffidon, E. I. (2004). New directions in African library management. Ibadan: Spectrum Books Limited. P. 134-137
Ifidon, I.E. (2008). Education and training of Nigerian librarians: the unrecognized crises. Paper presented at the $46^{\text {th }}$ National conference and Annual General meeting of Nigerian Library Association at Kaduna from 1-6 June 2008, 29-40.

Lockhart \& Majal (2007).The effect of library staff training and development on the user experience.https://www.cpt.za/storag e/research/reports/research-report2012.

Noe, R. A. (2010). Employee training and development. $5^{\text {th }}$ ed. New York: McGraw-Hill/Irwin.

Obi, R. C. \& Zakari, M. (2007).Employee training and development: the tool for self reliance and sustainable development. International Journal of Labour and Organizational Psychology,1(1\&2):128-135.

Obi, R. C. (2013).A review of the Role and Problems of personnel training and the success of academic libraries in Nigeria. Journal of Research in Education and Society, 4 (1)

Obichere, C. C. (2013). Personnel management in Academic libraries in Imo state: Issues, problems and prospects. Journal of Nigerian Library Association, Imo State Chapter 6(1\&2):37-50.

Oduagwu, E. A. (2006). Libraries and Information Management in a Globally Networked Society. Owerri, Imo state. Tony Ben publishers, 189-190.

Ogbonna, O. E. (2002). Staff Development Programmes of Professional Librarians in Federal polytechnic, Nekede, library and Alvan Ikoku College of Education library Owerri. A Research Study for the Award of HND at Federal Polytechnic Nekede, Owerri, Imo state. 
Iwuchukwu, Charity O. and Echedom, Anthonia U.: Staff training and development programmes in academic libraries in Imo State, Nigeria

Okafor, J. I. (2007). Staff training and development in university library: a case of Nnamdi Azikiwe university library, Awka. Research Project Submitted to the Department of Library and Information Science in partial fulfillment of the award of HND at Federal Polytechnic, Nekede, Owerri Imo state.

Olaniyan, A. \& Ojo L.B. (2008). Assessing Training Needs of LIS Professionals. www.whiteclouds.com/ic|cc|iej|c1.37BN.pdf.

Onwubiko, C.P. (2004). Fundamentals of management in libraries. Owerri : Remd Publisher. abiastateuniversity.edu.ng $>$ cpc.on-------inlibs.

Onyia, N.G. \& Anibolu , C.A. (2011).The effects of training and retraining on job performance: the Delta state polytechnic Ogwashiuku Library Staff Experience. International Journal of Labour and Organizational Psychology 5(1\&2).

Osiegbemha, A. (2007). Staff training and development programmes in academic libraries: a case study of the University of Port Harcourt library. Owerri, Imo state. Research Study for the Award of HND at Federal Polytechnic, Nekede, Owerri, Imo State.

Reynolds (2002). The impact of staff training on the knowledge and confidence of employee. nrl.northumbria.ac.uk/.../1/bereavem ent-1D-Authors'-version.

Stone, R. (2002). Human Resources Management $5^{\text {th }}$ ed. Sydney: John Wiley and sons

Ugwuanyi, C. F. \& Ejikeme, A. N. (2011). Awareness of the expected skill sets and development required by new era librarians in academic libraries in South Eastern Nigeria. Paper Presented at NLA Conference held in Anambra state in 2011, 102-115.

Yan, Lei (2004). Training library staff to adapt to the internet environment. www.white-clouds.com/../cliejhtm.

Yusuf, T.M. (2000). The human factor in national development. Benin City, Nigeria: University of Benin Press and Spectrum books ltd. https://www.semantiescholar.org > T- 